\title{
Bioethics and animal research. A personal perspective and a note on the contribution of Fritz Jahr ${ }^{1}$
}

\author{
FERNANDO LOLAS
}

Interdisciplinary Center for Bioethics, University of Chile (Collaborating Center of the World Health Organization) Bioethics Program, Pan American Health Organization, E-mail: lolasf@chi.ops-oms.org

\begin{abstract}
Reviewing fundamental aspects of bioethics and outlining the work of the Bioethics Program of the Pan American Health Organization, this paper draws attention to the work of a forgotten pioneer- Fritz Jahr- who coined the term bioethics in 1927 and anticipated many of the arguments and discussions now current in biological research involving animals-
\end{abstract}

Key terms: Bioethics, Biological research, Pan American Health Organization, Fritz Jahr.

RESEARCH: INVENTION, INNOVATION AND TRANSFORMATION

Research is the core activity of modern science and technology and can be defined as the production and dissemination of valid, reliable and generalizable knowledge. Knowledge is not simply information, but information organized according to a legitimate social interest (utility, beauty, education, profit) (Lolas, 1998, 2000).

Three social processes comprise research. Invention is the creation of new concepts or ways of constructing observational realities. It increases intellectual input and may be considered the type of research that professional scientists value most, usually calling it "fundamental" or "basic". Innovation is the creation of new ways of applying or modifying realities uncovered by invention. It increases practical output. Hence, the term "applied" usually used in connection with medicine and engineering, for example. Transformation is the modification of persons and institutions as a result of knowledge production. It is usually the intellectual impact of the humanities and the social sciences, whose contribution sometimes does not produce new data or new applications but new ways of interpreting reality and human works.

All three processes may be involved in research but usual practice tends to separate them and produce independent communities. Teams involved in invention (or basic research) may or may not engage in innovation (applied research). Nevertheless, transformation is a result of research at institutional and personal levels. Institutions not engaged in research are different from those having this activity as one of their missions or objectives.

Since research (and not erudition) is the core of science as social practice, it necessarily involves risks, benefits, and harms that may affect the lives of persons, groups, or societies. From the moral standpoint, all research has consequences, as historical lessons show. This means that every human action, even no action, has moral consequences, irrespective of the way in which people choose to analyze it (religious, philosophical, etc.). All human activities are subject to ethical scrutiny, since ethics is the rational reflection about moral life and its effects on humanity. The

1 During the preparation of this paper, the author received support from the Alexander von Humboldt Foundation at the University of Heidelberg, Germany 
two most common ethical traditions of Western thought -deontology, or the theory of duties, and teleology, the theory of consequences- have become associated in the discourse of current bioethics, which can be conceived of as social process, disciplinary matrix or procedure for reaching conclusions, and academic product.

\section{BIOETHICS: THE WORD AND ITS MEANING}

The first documented use of the word bioethics dates back to 1927, when Fritz Jahr, a protestant pastor and theologian from Halle, gave the title "Bio-Ethik: Eine Umschau über die ethischen Beziehungen des Menschen zu Tier und Pflanze" to an article published in the journal Kosmos. (Jahr, 1927).

The main idea behind Jahr's article was to anticipate what he later called "the bioethical imperative" (Jahr, 1934). Paraphrasing Immanuel Kant with the categorical imperative, Jahr suggested that all living beings were entitled to respect and should be treated not as means but as ends in themselves (Engel, 2004; Sass, 2007a, b).

Distancing himself from the teachings of Hindu scholars whose viewpoints could be confused with his own, Jahr addressed the biblical Fifth commandment (prohibition to kill) in its implications for the welfare of animals and plants and examining, mostly from a theological point of view, what can be considered a "humane" treatment of living beings. In his1934 paper, he asserts that the bioethical imperative is self evident in relation to animals, in the sense that it appeals to conscience not to torture or otherwise inflict damage on animals (referring mostly to mammals) but that plants should be accorded similar treatment. And concludes "Als Umschreibung des fünften Gebotes ergigt sich der bio-ethische Imperativ: "Achte jades Lebewesen grundsätzlich als einen Selbstzweck und behandle es nach Möglichkeit als solchen!"(Jahr, 1934).

It should be recalled that the Zeitgeist of the first decades of the XXth century produced in Europe a curious fusion between laws and regulations placing limits on medical experimentation and legislations later considered discriminatory and inhuman, not only in Germany but in other countries as well. At the time of the Republic of Weimar, when Jahr writes, Julius Moses had been able to pass legislation on proper human experimentation (1931) that some doctors during the Nazi regime did not comply with, as demonstrated by the Nuremberg trial of doctors and its impact on research practice (Weizsäcker, 1947; Eckart, 2008).

This is not the place to trace the origins and evolution of Jahr's concept of bioethics and the developments it accompanied or anticipated at a time characterized by a complex mixture of nationalist sentiments, heroic nihilism, and political turmoil. Suffice only to say that its relevance for biological research employing animals is still open for discussion.

In the decade of the seventies of the XXth century Van Rensselaer Potter also used the term meaning a wide consideration of solidarity in the biosphere. He later insisted on his proposal of a "global ethics", a science of survival for the human and other animal species (Potter, 1970, 1971).

During the last decades of the XXth century the term was employed in a variety of contexts. Two main streams can be discerned: an application of ethical reasoning to medicine and the health sciences and a general ethical standpoint for the analysis of science and technology. Initiatives linking the humanities and the natural sciences and the coalescence of "cultures" have been in the Zeitgeist of the XXth century (Lolas, 1998, 2002)

Different meanings of the word "bioethics" make it difficult to formulate a definite set of principles constituting a consolidated discipline. Resistance to its use has been observed in some European countries. In the developing world, some have used the term with political intention to question developments in industrialized countries. Resource-poor settings have accepted bioethical concepts inspired by European and North American institutions.

Currently, bioethics is an umbrella term covering different attempts to humanize the scientific enterprise, the practice of the 
health professions, and the respect for human rights in economics, politics, and social research

\section{VARIETIES OF BIOETHICS}

It is no wonder that with such diverse origins and usages, many forms of bioethics can be discerned. Topics addressed by bioethics have a long past but a short history (Lolas 2002a).

One aspect relates to basic and applied research with human and animal subjects. Medical consequences of advances in genomics, organ transplantation, stem cell research and biotechnology along with their ethical, legal, and social implications constitute an expanding area of bioethical reflection.

Bioethics has also analyzed the interface between scientific communities and lay people. Politicians, legislators, entrepreneurs, without formal scientific training need to be informed about science and technology in order to make informed decisions on resource allocation, public policy and regulatory practices. Cases contributing to the visibility of bioethics have been violations of moral codes disseminated through public media. Without such exposure, important documents such as the Nuremberg Code, the Declaration of Helsinki, the Belmont Report or the CIOMS Guidelines would not have received attention (Lolas, 2001)

Delivery of services, priority setting in national or international contexts, respect for human rights and solidarity or reciprocity in dealing with vulnerable populations or ethnic minorities belong also to the bioethical enterprise (Lolas et al, 2007)

Considering these different domains, bioethics is clinical, research-oriented, regulatory, cultural and commonsense. Its practice is influenced by religious, gender (feminist bioethics) and political considerations.

\section{THE PRACTICE OF BIOETHICS}

In many regions of the world, Latin America included, the common form of bioethics practiced to-day is principialism. The most widespread form of reasoning is based on so-called intermediate principles, between higher order values and rules of conduct. The principles outlined in several documents like the Belmont Report, Declaration of Helsinki, CIOMS Ethical Guidelines and others are autonomy (respect for persons), beneficence, nonmaleficence and justice. Some authors add trustworthiness, reciprocity, solidarity, truthfulness, relevant to the pursuit of scientific research including project planning, data collection, sampling, and publication (Beauchamp \& Childress, 2001; CIEB, 2008).

The essential thrust of bioethics is the dialogical nature of decision making, based on deliberation. All stakeholders and beneficiaries of research and innovation should partake of the ideas, risks, benefits, and outcome of research. This includes sponsors, researchers, administrators, service providers, research subjects and public at large.

One implication of bioethics for the conduct of research is the need to share information, decision, and outcome beyond the scientific community to those who may use or apply scientific knowledge. A code of ethics for scientists should include provisions for obtaining and maintaining public trust on the self-regulation of science and technology. Most of the classical documents elaborated so far derive from situations in which rights of persons or animals were violated or not adequately respected in the name of scientific progress.

\section{INSTITUTIONALIZATION OF BIOETHICS}

The dialogical nature of bioethics has created new social institutions or reshaped old ones. For research, research ethics committees, called Institutional (or Independent) Review Boards in the US and Data Safety and Monitoring Boards to review, approve, and follow up projects.

Experience suggests that research ethics committees should be close to the institutions, be integrated by members without conflicts of interest related to the 
projects under evaluation and by lay people, lawyers, priests and other experts.

There exist also committees charged with oversight of clinical practice (hospital ethics committees) or associated with professional organizations. At the level of states, provinces, or nations, some countries have higher-level commissions for addressing conflicts or clarifications arising from ethical oversight or for formulating long term and long range public policies.

A growing body of literature is concerned with characteristics and operation of these different types of bioethical institutions (Cf. CIEB website)

\section{USES AND ABUSES OF BIOETHICS}

Bioethics is not simply application of philosophical notions to scientific problems or a new formulation of classical professional deontology. It is a dialogic form of deliberation considering social interests and the cultural or religious norms about what is proper, what is good and what is just. The institution of the committee or the consultative group stresses the social character of the bioethical enterprise. Bioethics can be misused as a political tool or as a means of exercising power. The potential usefulness of bioethical deliberation can be downgraded to antiscientific discourses and superficial admonitions against "ethical imperialism".

The program established by the Pan American Health Organization (PAHO) in association with the University of Chile and the Chilean government in 1994 aims to exercise ethical oversight over research with human subjects, evaluate health policies from an ethical point of view, and extend research and publication to ecological ethics, food ethics and animal research (Lolas, 2004, 2006 a,b, 2007). The commitment extends to ecological, biological, clinical, and social issues and is reflected in the flagship publication"Acta Bioethica (ISSN 0717-5906). It also maintains a virtual library on bioethics with the support of BIREME (http: //bioetica.bvsalud.org/htmal/ es/home.html), publishes the newsletters Bioética Informa (ISSN 0717-6112) and
Salud Oral-Bioética (ISSN 0718-2392) and a series of books on research ethics, social bioethics, and clinical ethics, all freely available at the websites (Cf. PAHO BIO, 2008; CIEB, 2008)

\section{THE CONTRIBUTION OF FRITZ JAHR TO THE} BIOETHICS OF ANIMAL RESEARCH

As a theologian and educator, Fritz Jahr did not explicitly address scientific research with animals when he coined the term bioethics. Most of what has later been said, however, is anticipated in his writings. Beyond the "humane" conduct of research indicated by the famous "three Rs" (replacement, reduction, refinement) and the appropriate treatment of animals (Russell \& Burch, 1959; Cardozo et al., 2007), what is most remarkable is his notion of the "bioethical imperative". It summarizes without fanaticism or fundamentalism what is owed to animals as living beings, what can be reasonably expected from advances in the regulation of research and what the training of investigators should consider.

\section{REFERENCES}

BEAUCHAMP T L \& CHILDRESS J F (2001) Principles of Biomedical Ethics. New York: Oxford University Press, $5^{\text {th }}$ ed. (First edition 1979)

CARDOZO, C, MRAD A, MARTÍNEZ C, RODRÍGUEZ E, LOLAS F, editors (2007) El animal como sujeto experimental. Aspectos técnicos y éticos. Santiago de Chile: Centro Interdisciplinario de Estudios en Bioética Universidad de Chile. (available at www.uchile.cl/ bioetica)

CIEB (Centro Interdisciplinario de Estudios en Bioética, Universidad de Chile) http: //www.uchile.cl/bioetica

ECKART W (2008) Personal communication

ENGEL E M (2004) O desafio das biotécnicas para a ética e a antropología. Veritas 5: 205-228

JAHR F (1927) Bio-Ethik. Eine Umschau über die ethischen Beziehungen des Menschen zu Tier und Pflanze. Kosmos.Handweiser für Naturfreunde 24(1): 2-4

JAHR F (1934) Drei Studien zum 5. Gebot. Ethik. Sexualund Gesellschaftsethik 11: 183-187

LOLAS F (1998) Bioética. El diálogo moral en las ciencias de la vida. Santiago de Chile: Universitaria ( $2^{\mathrm{a}}$ edición Santiago: Mediterráneo, 2001)

LOLAS F (2000) Bioética y antropología médica. Santiago de Chile: Mediterráneo

LOLAS F (2001) Aspectos éticos de la investigación biomédica. Conceptos frecuentes en las normas escritas. Rev Méd Chile 129: 680-684

LOLAS F (2002a) Temas de bioética. Santiago de Chile: Universitaria 
LOLAS F (2002b) Bioética y Medicina. Santiago de Chile: Biblioteca Americana

LOLAS F, editor (2004) Diálogo y cooperación en salud. Diez años de bioética en la OPS. Santiago de Chile: Unidad de Bioética OPS/OMS, Organización Panamericana de la Salud. (available at www.paho.org/bioetica)

LOLAS F (2006a) Bioethics at the Pan American Health Organization: origins, developments, and challenges. Acta Bioethica 12: 113-119

LOLAS F, editor (2006b) Ética e innovación tecnológica. Santiago de Chile: Centro Interdisciplinario de Estudios en Bioética Universidad de Chile. (available at www.uchile.cl/bioetica)

LOLAS F (2007) El animal como sujeto experimental: una bioética para la ciencia de fronteras. In Cardozo, C. et al. (editors) El animal como sujeto experimental. Santiago de Chile: Centro Interdisciplinario de Estudios en Bioética U. de Chile, pp. 13-19

LOLAS F \& DE FREITAS DRUMOND G (2007) Fundamentos de uma antropología bioetica. São Paulo: Loyola / Centro Universitario São Camilo

LOLAS F, MARTIN D K \& QUEZADA A (2007)
Prioridades en salud y salud intercultural. Santiago de Chile: Centro Interdisciplinario de Estudios en Bioética Universidad de Chile

PAHO BIO (Pan American Health Organization Bioethics Program) http: //www.paho.org/bioetica

PESSINI L, DE BARCHIFONTAINE C \& LOLAS F (2007) Perspectivas de la bioética en Iberoamérica. São Paulo \& Santiago de Chile: São Camilo / OPS

POTTER V R (1970) Bioethics, the science of survival. Perspect Biol Med 14: 127-153

POTTER V R (1971) Bioethics: Bridge to the Future. Englewood Cliffs NJ: Prentice Hall

RUSSEL W M \& BURCH R L (1959) The principles of Humane Experimental Technique. London: Methuen

SASS H M (2007a) Fritz Jahr's bioethischer Imperativ. 80 Jahre Bioethick in Deutschland von 1927 bis 2007. Bochum: Zentrum für medizinische Ethik, Medizinethische Materialien Heft 175

SASS H M (2007b) Fritz Jahr's concept of bioethics. Kennedy Institute of Ethics Journal 17: 279-295

VON WEIZSÄCKER V (1947) “Euthanasie” und Menschenversuche. Psyche 1: 68-102 
